\title{
Interactive comment on "Identifying the non-exceedance probability of extreme storm surges as a component of natural-disaster management using tidal-gauge data from Typhoon Maemi in South Korea” by Sang-Guk Yum et al.
}

\section{Anonymous Referee \#2}

Received and published: 17 December 2020

Dear authors,

I read with interest your manuscript titled: "Identifying the non-exceedance probability of extreme storm surges as a component of natural-disaster management using tidal-gauge data from Typhoon Maemi in South Korea". The manuscript introduces a novel methodology for deriving non-exceedance probability diagrams of extreme surge storms. Clustered separated peaks-over-threshold simulation was developed, and various probability density function models were fitted to the empirical data for investigating the risk of storm surge height. Weibull probability density distribution was found to fit

Printer-friendly version

Discussion paper 
the empirical data. This manuscript introduce a novel simulation method for derivation of exceedance diagrams of storm surges that can contribute to many other natural hazards phenomena such as floods, forest fires, etc. The paper deserves minor revisions as follows: 1 . The title of the manuscript is too long consider shorter title such as: "Nonexceedance probability of extreme storm surges using tidal-gauge". 2. The abstract does not reflect the novelty of the methodology. Consider revision. 3. Please add a research framework diagram, emphasize the core phases of the methodology, particularly: the Threshold selection iterative process and the clustering of storm surge data. 4. The statistics analysis presentation: it is suggested to add Analysis of Variance output data for all regression and probabilistic distribution goodness of fit as follows: a. Please provide Coefficient of determination and correlationcofficiet, regression variance and Standard Error (SE) of the sea level fluctuations in Figure 4. Perhaps add a Table; b. Please provide detailed statistical data of the different probabilistic distributions I Figures 17-19. Please present the parameters of the selected distribution (Weibull) and discuss this with reference to the literature. c. Please discuss the statistical significance of the model ( $\mathrm{P}=$ Value, R2, C.I. P.I.). 5. Please elaborate the literature review with reference to up-to-date publications, please refer to (Ke et al. 2018; Catalano et al. 2019; McInnes et al. 2016; Silva-González et al. 2017; Hisamatsu et al. 2020; Buchana and McSharry 2019; Chen et al. 2019; Wahl et al. 2015; Bermúdez et al. 2019; Davies et al. 2017; Fawcett et al. 2016) with regards to exceedance diagrams and to (Zhu et al. 2017; Yum et al. 2020; Ke et al. 2018) with regards to storm surge risk assessment.

6. Please see further comments and typo-edit in the attached. 7. Some of the Figures need Legend and improved resolution. 8. Some references in the text are miss from the bibliographic list. Good Luck!

Ref.

Bermúdez, M., Cea, L., and Sopelana, J. (2019). "Quantifying the role of individual flood drivers and their correlations in flooding of coastal river reaches." Stoch Envi-

Printer-friendly version

Discussion paper
Interactive

comment

$\mathrm{C} 2$ 
ron Res Risk Assess, 33(10), 1851-1861, https://doi.org/10.1007/s00477-019-017338/. Buchana, P., and McSharry, P. E. (2019). "Windstorm risk assessment for offshore wind farms in the North Sea." Wind Energy (Chichester, England), 22(9), 12191229, https://doi.org/10.1002/we.2351/. Catalano, A. J., Broccoli, A. J., Kapnick, S. B., and Janoski, T. P. (2019). "High-Impact Extratropical Cyclones along the Northeast Coast of the United States in a Long Coupled Climate Model Simulation." Journal of Climate, 32(7), 2131-2143, https://doi.org/10.1175/JCLI-D-18-0376.1/. Chen, Y., Li, J., Pan, S., Gan, M., Pan, Y., Xie, D., and Clee, S. (2019). "Joint probability analysis of extreme wave heights and surges along China's coasts." Ocean Engineering, 177 97-107, https://doi.org/10.1016/j.oceaneng.2018.12.010/. Davies, G., Callaghan, D. P., Gravois, U., Jiang, W., Hanslow, D., Nichol, S., and Baldock, T. (2017). "Improved treatment of non-stationary conditions and uncertainties in probabilistic models of storm wave climate." Coastal Engineering (Amsterdam), 127 119, https://doi.org/10.1016/j.coastaleng.2017.06.005/. Fawcett, L., Fawcett, L., Walshaw, D., and Walshaw, D. (2016). "Sea-surge and wind speed extremes: optimal estimation strategies for planners and engineers." Stoch Environ Res Risk Assess, 30(2), 463-480, https://doi.org/10.1007/s00477-015-1132-3/. Hisamatsu, R., Tabeta, S., Kim, S., and Mizuno, K. (2020). "Storm surge risk assessment for the insurance system: A case study in Tokyo Bay, Japan." Ocean \& Coastal Management, 189, https://doi.org/10.1016/j.ocecoaman.2020.105147/. Ke, Q., Jonkman, S. N., van Gelder, P. H. A. J. M, and Bricker, J. D. (2018). "Frequency Analysis of Storm-Surge-Induced Flooding for the Huangpu River in Shanghai, China." Journal of Marine Science and Engineering, 6(2), https://doi.org/10.3390/jmse6020070/. Mclnnes, K., Hoeke, R., Walsh, K., O'Grady, J., and Hubbert, G. (2016). "Application of a synthetic cyclone method for assessment of tropical cyclone storm tides in Samoa." Nat Hazards, 80(1), 425-444, https://doi.org/10.1007/s11069-015-19754/. Silva-González, F., Heredia-Zavoni, E., and Inda-Sarmiento, G. (2017). "Square Error Method for threshold estimation in extreme value analysis of wave heights." Ocean Engineering, 137 138-150, https://doi.org/10.1016/j.oceaneng.2017.03.028/.

Printer-friendly version Discussion paper 
Wahl, T., Mudersbach, C., and Jensen, J. (2015). "Statistical Assessment of Storm Surge Scenarios Within Integrated Risk Analyses." Coastal Engineering Journal, 57(1), NHESSD https://doi.org/10.1142/s0578563415400033/. Yum, S., Kim, J. H., and Wei, H. (2020). "Development of vulnerability curves of buildings to windstorms using." Journal of Building Engineering, Article in Press. Zhu, Y., Xie, K., Ozbay, K., Zuo, F., and Yang, $H$. (2017). "Data-driven spatial modeling for quantifying networkwide resilience in the aftermath of hurricanes Irene and Sandy." Transp.Res.Rec., 2604(1), 9-18.

Interactive comment on Nat. Hazards Earth Syst. Sci. Discuss., https://doi.org/10.5194/nhess2020-379, 2020. 